\title{
Antimicrobial activity of the essential oil of Bowdichia virgilioides Kunt.
}

\author{
Jackson Roberto Guedes da Silva Almeida ${ }^{1}$, Raimundo Nonato da Silva-Filho ${ }^{2}$, Xirley Pereira \\ Nunes $^{2}$, Celidarque da Silva Dias ${ }^{2}$, Fillipe de Oliveira Pereira ${ }^{3}$, Edeltrudes de Oliveira Lima ${ }^{3 *}$
}

\author{
${ }^{1}$ Universidade Federal do Vale do São Francisco, Cx. Postal 252, 56306-410, Petrolina, Pernambuco, Brazil \\ ${ }^{2}$ Universidade Federal da Paraíba, Laboratório de Tecnologia Farmacêutica, Caixa Postal 5009, 58051-970, \\ João Pessoa, Paraíba, Brazil, \\ ${ }^{3}$ Universidade Federal da Paraíba, Departamento de Ciências Farmacêuticas, 58051-900, \\ João Pessoa, Paraíba, Brazil
}

\begin{abstract}
RESUMO: “Atividade antimicrobiana do óleo essencial de Bowdichia virgilioides Kunt.”. O óleo essencial das folhas de Bowdichia virgilioides Kunt. (Fabaceae) foi testado para a verificação da sua atividade antimicrobiana contra dezoito microorganismos patogênicos, usando o método de difusão em meio sólido. Foi observada atividade contra Candida albicans, Candida guilliermondii, Candida stellatoidea, Micrococcus luteus e Trichophyton rubrum.
\end{abstract}

Unitermos: Bowdichia virgilioides, Fabaceae, atividade antimicrobiana, óleo essencial.

\begin{abstract}
The essential oil of Bowdichia virgilioides Kunt. (Fabaceae) leaves was tested for their antimicrobial activity against eighteen pathogenic microorganisms using standard gel diffusion method. It showed activity against Candida albicans, Candida guilliermondii, Candida stellatoidea, Micrococcus luteus and Trichophyton rubrum.
\end{abstract}

Keywords: Bowdichia virgilioides, Fabaceae, antimicrobial activity, essential oil.

\section{INTRODUCTION}

Bowdichia virgilioides Kunt. (Fabaceae) is a medium size tree found in the tropical forests of South America. In Northeastern Brazil it is popularly known as "sucupira", and its bark is used for healing of wounds, as anti-ulcer and anti-diabetic (Bacchi, 1986; Oliveira; Saito, 1987-1989; Macedo; Ferreira, 2004) while the seeds are used in the treatment of rheumatism, arthritis, and skin diseases (Cruz, 1965). The importance of this plant promoted its inclusion in the first Brazilian Pharmacopoeia (Brandão et al., 2006). Various bioactivities, including antimalarial (Deharo et al., 2001), hypoglycemic (Barbosa-Filho et al., 2005) and inhibitor of the enzyme acetylcholinesterase (Barbosa-Filho et al., 2006), of crude extracts from this plant were reported. Previous chemical investigation resulted in the isolation of flavonoids (Velozo et al., 1999a; Velozo et al., 1999b; Arriaga et al., 2000; Juck et al., 2006), benzofuranoids (Melo et al., 2001), essential oil (Arriaga et al., 1998), triterpenoids (Torrenegra et al., 1985; Marinho et al., 1994; Melo et al., 2001) and alkaloids (Torrenegra et al., 1985; Torrenegra et al., 1989; Marinho et al., 1994; Barbosa-Filho et al., 2004). This work describes the antimicrobial activity of the essential oil of Bowdichia virgilioides.

\section{MATERIAL AND METHODS}

\section{Botanical material}

The plant was collected in December 2004, near the city of Santa Rita, State of Paraíba, Brazil, a coastal area around the Atlantic Forest. The voucher samples (Agra et Góis 6243) were deposited in the Herbarium Prof. Lauro Pires Xavier (JPB) and in the reference collection of the Laboratório de Tecnologia Farmacêutica from Universidade Federal da Paraíba, Brazil.

\section{Extraction of the essential oil}

Fresh leaves of Bowdichia virgilioides (1000 g) were cut into pieces, and subjected to steam distillation in a Clevenger-type apparatus (Matos et al., 1999). The essential oil obtained $(0.15 \% \mathrm{w} / \mathrm{w})$ had yellow color and characteristic odor and was dried over anhydrous sodium sulfate and filtered. The oil was kept in amber bottle flask and maintained in temperature lower than $4{ }^{\circ} \mathrm{C}$.

\section{Microorganisms}

For the bioassays 4 bacteria and 14 fungi were used: Staphylococcus aureus (ATCC 25923), 
Table 1. Halos diameter average $(\mathrm{mm})$ of the evaluation of the MIC of the essential oil of Bowdichia virgilioides against bacteria and fungi, in solid medium.

\begin{tabular}{|c|c|c|c|c|c|c|c|c|c|}
\hline \multirow[b]{2}{*}{ Microorganisms } & \multicolumn{6}{|c|}{ Essential oil (\%) } & \multicolumn{3}{|c|}{ Control } \\
\hline & 100 & 32 & 16 & 8 & 4 & 2 & 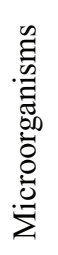 & 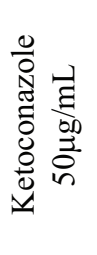 & 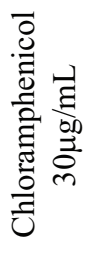 \\
\hline Staphylococcus aureus ATCC 25923 & 0 & 0 & 0 & 0 & 0 & 0 & + & - & 22 \\
\hline Staphylococcus epidermidis ATCC 12228 & 0 & 0 & 0 & 0 & 0 & 0 & + & - & 16 \\
\hline Micrococcus luteus ATCC 9341 & 10 & 8 & 0 & 0 & 0 & 0 & + & - & 20 \\
\hline Pseudomonas aeruginosa ATCC 27853 & 0 & 0 & 0 & 0 & 0 & 0 & + & - & 10 \\
\hline Candida albicans ATCC 90028 & 10 & 8 & 0 & 0 & 0 & 0 & + & 10 & - \\
\hline Candida guilliermondii LM 28 & 12 & 10 & 0 & 0 & 0 & 0 & + & 12 & - \\
\hline Candida krusei LM 07 & 0 & 0 & 0 & 0 & 0 & 0 & + & 0 & - \\
\hline Candida stellatoidea LM 96 & 10 & 8 & 0 & 0 & 0 & 0 & + & 14 & - \\
\hline Candida parapsilosis LM 1E & 0 & 0 & 0 & 0 & 0 & 0 & + & 10 & - \\
\hline Candida tropicalis LM 25 & 0 & 0 & 0 & 0 & 0 & 0 & + & 12 & - \\
\hline Trichosporon inkin LM 267 & 0 & 0 & 0 & 0 & 0 & 0 & + & 0 & - \\
\hline Cryptococcus neoformans M 570 & 0 & 0 & 0 & 0 & 0 & 0 & + & 8 & - \\
\hline Tricophyton rubrum LM 105 & 10 & 7 & 0 & 0 & 0 & 0 & + & 10 & - \\
\hline Tricophyton mentagrophytes LM 103 & 0 & 0 & 0 & 0 & 0 & 0 & + & 12 & - \\
\hline Penicillium FCF 281 & 0 & 0 & 0 & 0 & 0 & 0 & + & 0 & - \\
\hline Fusarium LM-10a & 0 & 0 & 0 & 0 & 0 & 0 & + & 0 & - \\
\hline Aspergillus flavus LM-136 & 0 & 0 & 0 & 0 & 0 & 0 & + & 10 & - \\
\hline Rhizophus LM 03 & 0 & 0 & 0 & 0 & 0 & 0 & + & 10 & - \\
\hline
\end{tabular}

Staphylococcus epidermidis (ATCC 12228), Micrococcus luteus (ATCC 9341), Pseudomonas aeruginosa (ATCC 27853), Candida albicans (ATCC 90028), Candida guilliermondii (LM 28), Candida krusei (LM 07), Candida stellatoidea (LM 96), Candida parapsilosis (LM 1E), Candida tropicalis (LM 25), Trichosporon inkin (LM 267), Cryptococcus neoformans (LM 570), Tricophyton rubrum (LM 105), Tricophyton mentagrophytes (LM 103), Penicillium (FCF 281), Fusarium (LM 10a), Aspergillus flavus (LM 136) and Rhizopus (LM 03).

\section{Culture media}

The assays for the antimicrobial activities were carried out in Muller-Hinton Agar (Merck) and Sabouraud Dextrose Agar (DIFCO Laboratories) for bacteria and fungi, respectively.

\section{Essays of antimicrobial activities}

The essential oil was tested "in natura" $(100 \%)$ and in dilutions from 32 until 2\%, according to Allegrini et al. (1973). For this purpose, $1.2 \mathrm{~mL}$ of the oil, $0.04 \mathrm{~mL}$ of Tween 80 (Sigma Chemical) and sterile distilled water enough to complete $5 \mathrm{~mL}$ were placed in sterile glass tubes, $70 \times 10 \mathrm{~mm}$ (32\% dilution). The resultant emulsion was homogenized in agitator Vortex (FANEM) for five minutes. The seriate dilutions were made in proportion of two. Beginning at the first tube, $2.5 \mathrm{~mL}$ were transferred to a second one, which contained $2.5 \mathrm{~mL}$ of sterile distilled water following by agitation and homogenization. This process was successively repeated until the sixth dilution, corresponding to $2 \%$. The tests performed to evaluate the antibacterial and antifungal activities of the volatile oil were carried out by the method of diffusion in solid media (Cleeland et al., 1991; Bawer et al., 1996; Hadacek; Greger, 2000). $1 \mathrm{~mL}$ of previously prepared suspension of each microorganism was deposited in dischargeable and sterile Petri dishes $(15 \times 90 \mathrm{~mm})$, to which were previously added $20 \mathrm{~mL}$ of ASD with slow homogenization. Cavities were made with sterile glass cannulas with $6 \mathrm{~mm}$ in diameter in the solid culture media and were inoculated with $50 \mu \mathrm{L}$ of each dilution of the tested oil. The controls were made for each microorganism with the standard antimicrobial chloramphenicol at 30 $\mu \mathrm{g} / \mathrm{mL}$ for bacteria, and ketoconazole at $50 \mu \mathrm{g} / \mathrm{mL}$ for fungi. The assay system was incubated at $37^{\circ} \mathrm{C}$, during $24-48$ hours for bacteria and leveduriforms fungi; and at room temperature in a period of $10-14$ days for the filamentous fungi. Each assay was carried out in duplicate and the results were expressed by arithmetic media of the halos of inhibition obtained. The biological activity of 
the oil was considered positive when the media of the inhibition of the halos were equal or superior to $10 \mathrm{~mm}$ in diameter.

\section{RESULTS AND DISCUSSION}

In the previous works, the oil of Bowdichia virgilioides fruits was reported to contain farnesol, geraniol and caryophyllene (Jorge-Neto, 1970). The volatile constituents from roots of the plant were reported (Arriaga et al., 1998). Antimicrobial activity from the essential oil of seeds was evaluated and it showed activity against Gram-positive Bacillus subtilis, Bacillus vulgaris, Enterococcus faecalis and Staphylococcus aureus and had low activity in vitro against Gramnegative Pseudomonas aeruginosa, Salmonella enteritidis and Escherichia coli (Feitosa et al., 2004). To our knowledge, there are no published reports on the chemical composition and antimicrobial activity of the essential oil from Bowdichia virgilioides leaves.

As part of this systematic research, the essential oils constituents of leaves were extracted by hydrodistillation in a Clevenger-type apparatus. The obtained crude essential oil was then investigated. Therefore, we focused our study on the antimicrobial property of the essential oil.

Composition and biological activity of the essential oils can vary with the climate, geographical area, seasons, soil conditions, crop period and extraction technique (Carvalho-Filho et al., 2006). The antimicrobial activity was tested in vitro by using standard gel diffusion method with the microorganisms as seen in Table 1.

\section{CONCLUSION}

In summary, the study of volatile constituents showed that the oil inhibited the growth of only one strain of the bacteria, when tested with the oil at the concentration of $100 \%$. Among all the fungi strains tested, only four were sensitive to the essential oil of B. virgilioides. The oil was active against Micrococcus luteus, Candida albicans, Candida guilliermondii, Candida stellatoidea and Trichophyton rubrum, being $C$. guilliermondii the most sensitive microorganism. These results led to the conclusion that the essential oil tested has a weak activity against the tested microorganisms. Further investigations looking at determination of new bioactive constituents should be carried out.

\section{ACKNOWLEDGEMENTS}

The authors are grateful to CAPES and CNPq (Brazil) for grants and fellowships and express their thanks to the College of Pharmacy of the University of Illinois, Chicago, USA, for granting access to the NAPRALERT database.

\section{REFERENCES}

Allegrini J, Bouchberg MS, Maillols H 1973. Emulsions d'huiles esentielles fabrication et applications en microbiologie. Societé de Pharmacie de Montpellier 33: 73-86.

Arriaga AMC, Machado MIL, Gomes GA, Craveiro AA 1998. Volatile constituents from roots of Bowdichia virgilioides Kunt. J Essent Oil Res 10: 205-206.

Arriaga AMC, Gomes GA, Braz-Filho R 2000. Constituents of Bowdichia virgilioides. Fitoterapia 71: 211-212.

Bacchi EM 1986. Ação antiúlcera e cicatrizante de algumas plantas brasileiras. Rev Bras Farmacogn 1: 93-100.

Barbosa-Filho JM, Almeida JRGS, Costa VCO, Da-Cunha EVL, Silva MS, Braz-Filho R 2004. Bowdichine, a new diaza-adamantane alkaloid from Bowdichia virgilioides. J Asian Nat Prod Res 6: 11-17.

Barbosa-Filho JM, Vasconcelos THC, Alencar AA, Batista LM, Oliveira RAG, Guedes DN, Falcão HS, Moura MD, Diniz MFFM, Modesto-Filho J 2005. Plants and their active constituents from South, Central, and North America with hypoglycemic activity. Rev Bras Farmacogn 15: 392-413.

Barbosa-Filho JM, Medeiros KCP, Diniz MFFM, Batista LM, Athayde-Filho PF, Silva MS, Cunha EVL, Almeida JRGS, Quintans-Júnior LJ 2006. Natural products inhibitors of the enzyme acetylcholinesterase. Rev Bras Farmacogn 16: 258-285.

Brandão MGL, Cosenza GP, Moreira RA, Monte-Mor RLM 2006. Medicinal plants and other botanical products from the Brazilian Official Pharmacopoeia. Rev Bras Farmacogn 16: 408-420.

Bawer AW, Kirby WM, Sherris SC, Turck M 1996. Antibiotic susceptibility testing by a standardized single disc method. Am J Clin Pathol 45: 493-496.

Carvalho-Filho JLS, Blank AF, Alves PB, Ehlert PAD, Melo AS, Cavalcanti SCH, Arrigoni-Blank MF, Silva-Mann $\mathrm{R}$ 2006. Influence of the harvesting time, temperature and drying period on basil (Ocimum basilicum L.) essential oil. Rev Bras Farmacogn 16: 24-30.

Cleeland R, Squires E 1991. Evaluation of new antimicrobials "in vitro" and in experimental animal infections In: Lorian V. (Ed.) Antibiotics in Laboratory Medicine, Williams \& Wilkins, 3a. Ed., Baltmore; 739-787.

Cruz GL 1965. Livro Verde das Plantas Medicinais e Industriais do Brasil, Belo Horizonte, Helmus Ed., 779.

Deharo E, Bourdy G, Quenevo C, Munoz V, Ruiz G, Sauvain M 2001. A search for natural bioactive compounds in Bolivia through a multidisciplinary approach. Part V. Evaluation of the antimalarial activity of plants used by the Tacana Indians. J Ethnopharmacol 77: 91-98.

Feitosa JGR, Silva ES, Rodrigues MO, Alves PB 2004. Atividade antimicrobiana do óleo essencial de Bowdichia virgilioides pelo método de difusão em placa. XXVII Reunião Anual da Sociedade Brasileira de Química. Salvador, Brasil.

Hadacek F, Greger H 2000. Testing of antifungal natural products: methodologies, compatibility of results and assay choice. Phytochem Analysis 11: 137-147.

Jorge-Neto J 1970. Pharmacognostic study of essential oil of sucupira, Bowdichia virgilioides. Rev Fac Farm Odontol Araraquara 4: 203-204.

Débora B. F. Juck DBF, Rezende LC, David JP, Queiroz 
LP, David JM 2006. Two new isoflavonoids from Bowdichia virgilioides. Nat Prod Res 20: 27-30.

Macedo M, Ferreira AR 2004. Plantas hipoglicemiantes utilizadas por comunidades tradicionais na Bacia do Alto Paraguai e Vale do Guaporé, Mato Grosso-Brasil. Rev Bras Farmacogn 14(Supl. 1): 45-47.

Marinho LC, Cunha MTMC, Thomas G, Barbosa-Filho JM 1994. Constituents of Bowdichia virgilioides. Fitoterapia 65: 475.

Matos FJA, Machado MIL, Craveiro AA, Alencar JW, BarbosaFilho JM, Cunha, EVL, Hiruma CA 1999. Essential oil of Mentha x villosa Huds. from Northeastern Brazil. $J$ Essent Oil Res 11: 41-44.

Melo FN, Navarro VR, Silva MS, Cunha EVL, BarbosaFilho JM, Braz-Filho R 2001. Bowdenol, a 2,3dihydrobenzofuran constituent from Bowdichia virgilioides. Nat Prod Lett 15: 261-266.

Oliveira O, Saito ML 1987-1989. Alguns vegetais brasileiros empregados no tratamento do diabetes. Rev Bras Farmacogn 2-4: 170-196.

Torrenegra R, Escarria S, Bauereiss P, Achenbach H 1985. The major alkaloid of the bark from Bowdichia virgilioides. Planta Med 51: 276-277.

Torrenegra R, Bauereiss P, Achenbach H 1989. Homoormosanine-type alkaloids from Bowdichia virgilioides. Phytochemistry 28: 2219-2221.

Velozo LSM, Silva BP, Bernardo RR, Parente, JP 1999a. Odoratin-7-O- $\beta$-D-glucopyranoside from Bowdichia virgilioides. Phytochemistry 52: 1473-1477.

Velozo LSM, Silva BP, Silva BEM, Parente JP 1999b. Constituents from the roots of Bowdichia virgilioides. Fitoterapia 70: 532-535. 